\title{
The Effect of Nuclear Ownership on Utility Bond Ratings and Yields
}

\author{
R. J. Nesse
}

February 1982

Prepared for the U.S. Department of Energy under Contract DE-AC06-76RLO 1830

Pacific Northwest Laboratory Operated for the U.S. Department of Energy by Battelle Memorial Institute 


\title{
DISCLAIMER
}

This report was prepared as an account of work sponsored by an agency of the United States Government. Neither the United States Government nor any agency thereof, nor any of their employees, makes any warranty, express or implied, or assumes any legal liability or responsibility for the accuracy, completeness, or usefulness of any information, apparatus, product, or process disclosed, or represents that its use would not infringe privately owned rights. Reference herein to any specific commercial product, process, or service by trade name, trademark, manufacturer, or otherwise, does not necessarily constitute or imply its endorsement, recommendation, or favoring by the United States Government or any agency thereof. The views and opinions of authors expressed herein do not necessarily state or reflect those of the United States Government or any agency thereof.

\author{
PACIFIC NORTHWEST LABORATORY \\ operated by \\ BATTELLE \\ for the \\ UNITED STATES DEPARTMENT OF ENERGY \\ under Contract DE-AC06-76RLO 1830
}

\begin{tabular}{|c|c|}
\hline \\
\hline \multicolumn{2}{|c|}{$\begin{array}{c}\text { National Technical Information Service } \\
\text { United States Department of Commerce } \\
5285 \text { Port Royal Road } \\
\text { Springfield, Virginia } 22151\end{array}$} \\
\hline \multicolumn{2}{|c|}{$\begin{array}{l}\text { NTIS Price Codes } \\
\text { Microfiche A01 }\end{array}$} \\
\hline \multicolumn{2}{|c|}{ Printed Copy } \\
\hline Pages & $\begin{array}{l}\text { Price } \\
\text { Codes }\end{array}$ \\
\hline $001-025$ & $\mathrm{~A} 02$ \\
\hline $026-050$ & $\mathrm{~A} 03$ \\
\hline $051-075$ & $\mathrm{~A} 04$ \\
\hline 076-100 & A05 \\
\hline $101-125$ & A06 \\
\hline $126-150$ & $\mathrm{~A} 07$ \\
\hline $151-175$ & $\mathrm{~A} 08$ \\
\hline $176-200$ & $\mathrm{~A} 09$ \\
\hline $201-225$ & A010 \\
\hline $226-250$ & A011 \\
\hline $251-275$ & A012 \\
\hline $276-300$ & $A 013$ \\
\hline
\end{tabular}


THE EFFECT OF NUCLEAR OWNERSHIP ON UTILITY BOND RATINGS AND YIELDS

R. J. Nesse

February 1982

Prepared for the U.S. Department of Energy under Contract DE-AC06-76RLO 1830

Pac if ic Northwest Laboratory Richland, Washington 99352 


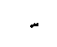




\section{SUMMARY}

The last 10 years have been extraordinary for the electric utility industry. The industry has experienced a number of problems. Not only have utilities had to cope with rapidly increasing costs and construction problems, but inflation and regulatory lags have prevented them from passing their problems onto their customers. Added to these problems was the accident at Three Mile Island Nuclear Power Plant. The magnitude of the accident left the electric industry, investors, and the general public stunned and concerned about the safety of nuclear power.

The major objective of this study was to test the hypothes is that investors, because of the abovementioned problems, have required an additional interest rate premium before purchasing bonds of utilities with large investments in nuclear facilities.

The study required several tasks. First, the literature relating to firm bankruptcy and default was reviewed. Second, the failing financial health of the electric utility industry was assessed in terms of construction problems, the impact of federal and state regulations, and the impact of Three Mile Island. Finally, data were collected on 63 electric utilities. This allowed statistical estimation of the magnitude of the risk premium associated with utility involvement in nuclear power. The effect of this involvement on a utility's bond ratings was also examined. Multiple regression was the statistical tool used for the statistical testing and estimation.

The statistical analys is revealed that problems in the electric utility industry have not gone unnoticed by investors or bond raters. Utilities with a high percentage of their electricity generated by nuclear power plants were found to have statistically significant lower bond ratings. The results were less clear, however, for bond interest rates. There are three possible reasons for this: 1) the effect on bond interest rates of nuclear participation could show up via reduced bond ratings, 2) the impact on bond interest rates of nuclear participation could be obscured by the inability to hold constant all of the bonds' terms, or 3) nuclear participation does not matter to investors. 


\section{.}




\section{CONTENTS}

SUMMARY

i i

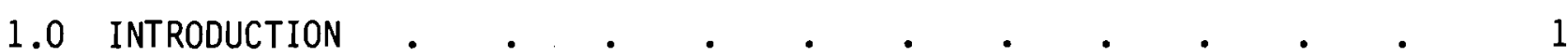

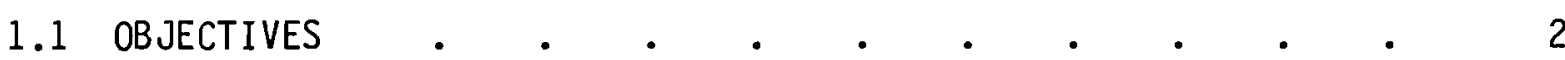

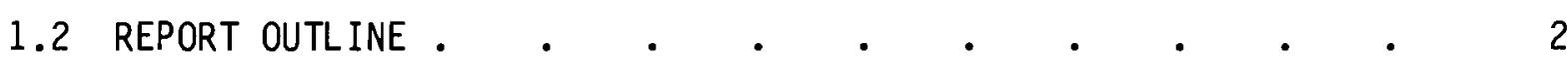

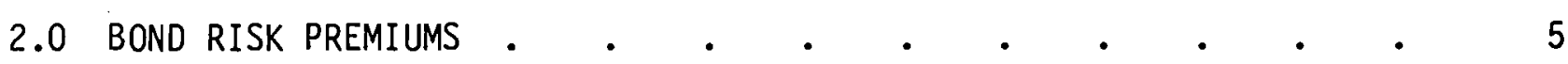

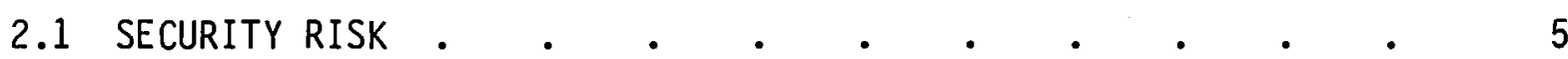

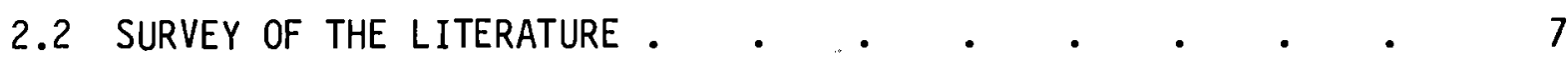

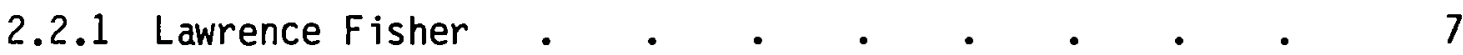

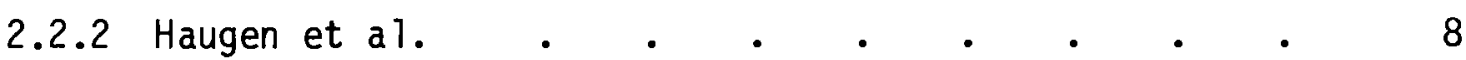

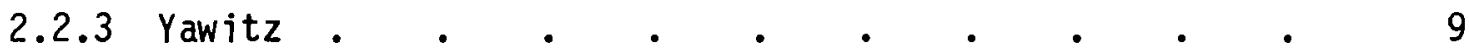

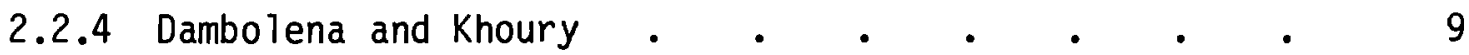

3.0 THE ELECTRIC UTILITY INDUSTRY •

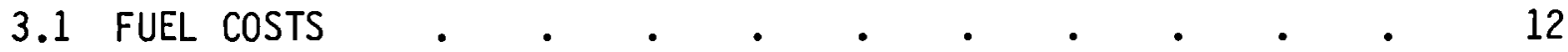

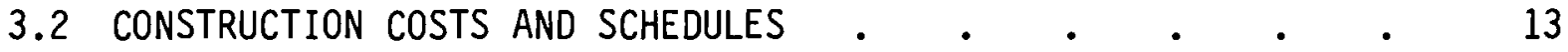

3.3 REGULATIONS $\quad$ • . . . . . . . . . . . . . . . . . 16

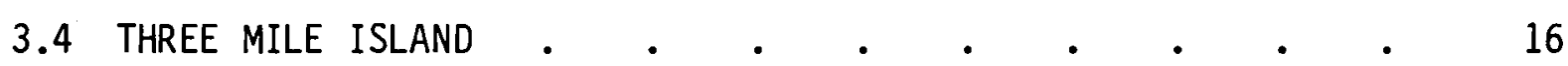

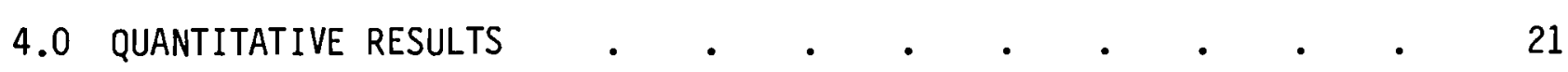

4.1 MULTIPLE REGRESSION •

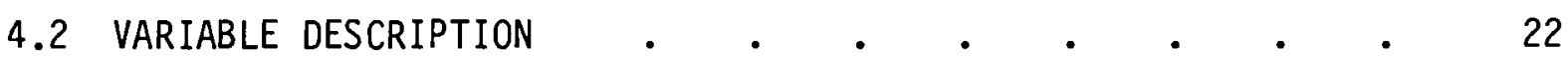

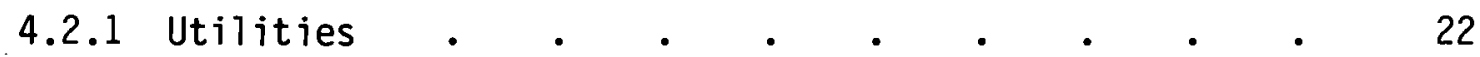

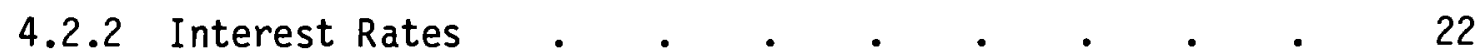

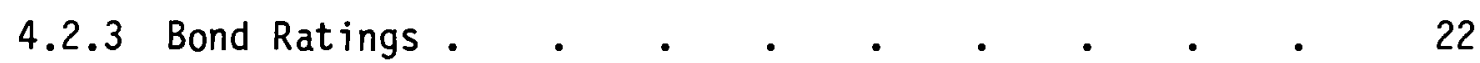

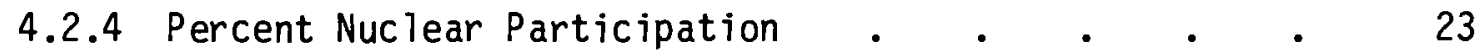

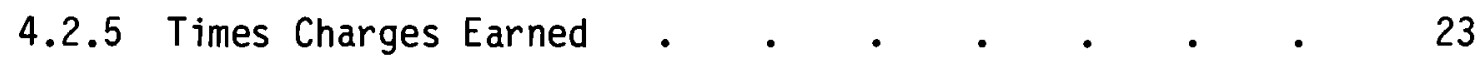

4.2.6 State Regulatory Quality . . . . . . . . . 24 
4.2.7 Three Mile Island . . . . . . . . . . . . 24

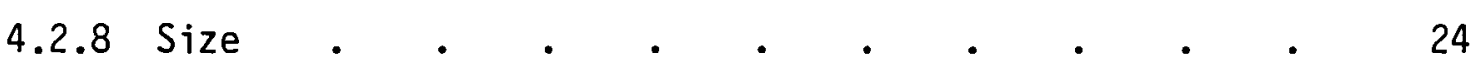

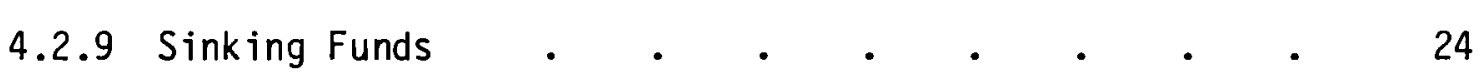

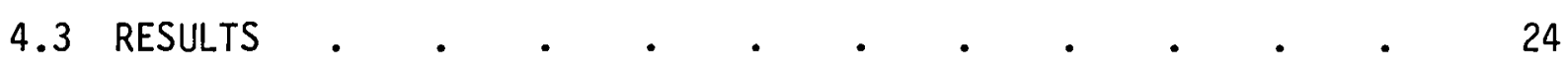

4.3.1 Bond Ratings . . . . . . . . . . . . 25

4.3.2 Bond Interest Rates . . . . . . . . . 26

5.0 CONCLUSIONS $\quad$ •

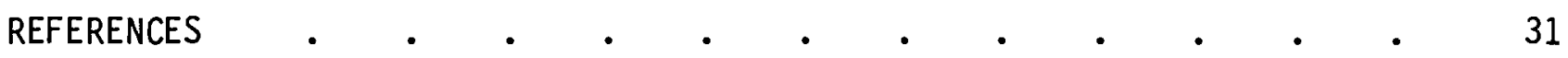

FIGURE

3.1 Yearly Growth in NRC Regulatory Guides . . . . . . . 17

$\underline{\text { TABLES }}$

3.1 Market-to-Book Values for 64 Largest Electric Utilities . . . 11

3.2 Standard and Poor's Ratings of Utility Long-Term Debt . . . 12

3.3 Annual Percentage Change in Fuel Costs . . . . . . 13

3.4 Results of Econometric Modelling of Construction Length . . . 15

4.1 Regression Results for Bond Ratings . . . . . . . . 25

4.2 Regression Results for Bond Yields . . . . . . . . 27 


\subsection{INTRODUCTION}

Th is research was supported by a Pacific Northwest Laboratory (PNL) interna 1 fund ing source from the U.S. Department of Energy that attempts to identify and support projects of potential interest to PNL sponsors. The objective of this project was to confirm whether or not a cost of capital risk premium exists for investments in nuclear power plants. Since internal support was limited, the scope of this project was constrained to an initial investigation of the issues surrounding debt financing of nuclear power plants.

Historically, the cost of debt to electric utilities has been very low. One reason for this is the ability of regulated utilities to pass through most cost increases to consumers. For the bondholders, this means a cash flow sufficient to cover interest payments and any maturing debt. Thus, the risk of a utility defaulting on its interest payments or bond repayments is small.

Recent concern about the financial health of the electric utility industry has escalated to concern that a default might occur. There are several reasons for the growing alarm. First, the overall financial health of the electric utility industry is slowly deteriorating. In part, this is caused by the various construction problems faced by many electric utilities. In particular, nuclear power plants are experiencing lengthy construction delays and cost overruns. The construction problems plus high market interest rates have forced utilities to pay higher interest rates on larger than expected debt.

A second reason for concern over utility default or bankruptcy is the impact of the nuclear accident at Three Mile Island Nuclear Power Plant (TMI). The incident at TMI has increased doubts about the safety of nuclear power and raised concerns about the costs and liability of future accidents. The effects of the accident on TMI's owner, General Public Utilities, have been devastating. Costs may run as high as $\$ 1$ billion dollars. State and federal regulators are considering removing General Public's operating license.

Since the cost of debt is a major component of the cost of capital, it is an important determinant in utilities' decisions whether to build nuclear or coal plants. Because nuclear plants are relatively capital intensive and require longer construction periods than coal plants, an increase in the 
cost of debt for constructing nuclear plants will create a large disincentive to build nuclear plants. We expect the problems with nuclear facilities to be reflected in utilities' decisions whether to build coal or nuclear power plants. The longer construction lengths and uncertain interest rates should cause cash flows associated with nuclear plants to have higher variance than cash flows for coal facilities; therefore, we expect investors to charge a $r$ isk premium for funds to be used in the construction and operation of nuclear facilities. That is the hypothes is we wish to test in this paper.

\subsection{OBJECTIVES}

The overall objectives of this effort are to test the hypothes is that default premiums exist for utilities with large investments in nuclear facilities and to estimate the magnitude of the default premium for nuclear facilities. To achieve these objectives, several tasks were accomplished:

1. Literature relating to default and bankruptcy risk was reviewed.

2. Issues relating to utility default and bankruptcy, including the financial health of electric utilities, construction problems, and the effect of the accident at Three Mile Island, were examined.

3. The hypothesis that a differential risk premium exists for utilities with large nuclear investments was tested.

4. The magnitude of the risk premium was estimated.

Since the scope of this paper is limited to an initial analys is of the default and risk premiums associated with nuclear plants, the quantitative analys is (Tasks 3 and 4 ) is somewhat limited.

\subsection{REPORT OUTLINE}

The report is organized similar to the organization of the original research. There are four sections following this introduction:

Section 2, Bond Risk Premiums, is a summary of academic literature and research on default risk. 
Section 3, The Electric Utility Industry, is a review of the financial health of the electric utility industry. Discussed in this section is the failing financial health of the industry in terms of construction problems, the impact of federal and state regulations, and the impact of the accident at Three Mile Island.

Section 4, Quantitative Results, is a review of data collected for this analysis and the results of statistical testing and analysis of the hypothesis that a differential risk premium exists for utilities with large nuclear investments.

Section 5, Conclusions, is a brief statement of some of the major conclusions drawn by this study. 


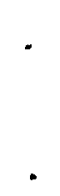




\subsection{BOND RISK PREMIUMS}

There is risk involved in any form of security investment. For some securities, such as government bonds of large stable countries, the risk is minimal. In the absence of insurrection, war or other such calamity, a government can always pay off its debt through forced taxation or by printing money. However, even purchasers of U.S. Treasury Bills encounter the risk of seeing the value of their investments reduced by inflation. Risk can be minimized, but never eliminated.

There are are a variety of hazards and risks associated with investing in securities. The first part of this section reviews several possible pitfalls encountered by a security investor and emphasises the risk of investing in longterm bonds. The second part reviews several articles that are important for a discussion of utility bond risk premiums.

\subsection{SECURITY RISK}

For this study, we use "risk" to mean the chance that the outcome will differ from its expected value. For an investment in a security, this means the possibility that the cash flows from investing in the security will differ from those expected. Since for most investors an increase in the level of uncertainty is a negative attribute, the typical investor will require additional compensation to accept higher levels of risk. For bonds, the higher level of compensation can be expected to take the form of higher interest rates.

In a period of highly uncertain inflation, one of the most significant sources of risk is the possibility of a deterioration of the security's value or the value of the interest payment because of changes in the inflation rate. Since bonds represent fixed payments, an increase in inflation reduces the value of the payment. As a result of inflationary expectations, investors include an added provision to account for the expected decline in the value of the payment. This provision is referred to as the inflationary premium. For a bond with very little other sources of risk, such as a U.S. Treasury Bill, the changes in interest rates often are reflective of changing inflationary premiums . 
Once we have included an inflationary premium into our required returns, any deviation from the expected rate of inflation will increase or decrease our returns. For example, suppose in the absence of any inflation a bond would yield 5\%. If we expect inflation to be $8 \%$, the resulting interest rate will be 13\%. If the actual inflation turns out to be on $1 y 3 \%$, we will have a larger real return than expected. However, if the actual inflation turns out to be $12 \%$, the purchasing power of our returns will be unexpectedly low.

A second source of risk for a bond investor is the possibility of capital gains or losses in the value of the bond as interest rates change. The interest rate fluctuates as the Federal Reserve System increases or decreases the money supply or as credit becomes tighter or more relaxed. An increase in the interest rate will cause bond prices to fal1 and the reverse occurs as interest rates decline. Since the issuer of the bond pays the principal at maturity, an individual can avoid this risk by investing in bonds that will soon mature.

A third source of risk for the bond investor is the possibility of the company being unable to meet a legal, contractual obligation such as an interest payment or a principal repayment. When a default on an obligation occurs, the injured party can force the firm into bankruptcy. The owner or potential buyer of a bond is concerned with the firm meeting all of its obligations, since the risk of bankruptcy is not only that the firm may not pay interest or principal on his bond but on any of the firm's obligations. The bankruptcy forces the firm into court to determine if the creditor's claims can be best met by allowing the firm to continue to operate or by liquidating the firm and using the resulting cash to settle the creditor's claims. The bankruptcy increases the uncertainty of the amount and timing of the creditor's claims.

As might be expected, the introduction of the possibility of bankruptcy increases the cost of debt. Consider the following example (Higgins 1977, p. 195): Suppose in the absence of any possibility of bankruptcy, the rate of interest is $10 \%$. Now, suppose there is a $5 \%$ chance of bankruptcy. If bankruptcy occurs, creditors collect only $40 \%$ of the money owed them. For any promised interest rate, $r$, the expected income to the lender of $\$ 1000$ is:

$$
(95 \%)(1000)(1+r)+(5 \%)(.4)(1000)-1000=970(1+r)-1000
$$


If the lender's expected return is to remain at $10 \%(\$ 100)$, then the promised rate must be increased to $13.4 \%$. (Found by the equation $970(1+r)-1000=$ 100.) In order to provide the lender with the same return, the firm with a possibility of bankruptcy must offer a higher interest rate. In addition, since bankruptcy increases the variation of returns, a risk-adverse investor will require a still higher rate of return. Similarly, any increase in the probability of default will increase the required interest rate.

Historically, the chances of a utility bankruptcy are very slight. There are several reasons for the historically low default rate for utilities. As a regulated monopoly, they have been able to request rate increases and pass most cost increases on to the ir customers. Until recently, demand for the ir products has been steadily increasing while costs have been falling. Recently, however, utilities have experienced a number of financing and construction problems. For reasons discussed in the next section, individual utilities are facing increasing possibilities of default.

\subsection{SURVEY OF LITERATURE}

The literature on bankruptcy risk and risk premiums on bonds was examined. The goal of the literature search was to find articles that would provide empirical or theoretical evidence of the factors influencing the risk premium on utility bonds. Unfortunately, very few of the articles on bankruptcy were particularly helpful for this study. The few exceptions are reviewed below.

\subsubsection{Lawrence Fisher, Determinants of Risk Premiums on Corporate Bonds}

Fisher's article was an early attempt to identify and test hypotheses about the determinants of risk premiums on corporate bonds. Fisher uses risk premiums to refer to the difference between a bond's yield and the risk-free interest rate. His hypothesis is that risk premiums depend on the risk that a firm will default on its bonds and the bond's marketability. He uses the coefficient of variation, the length of time the firm has been solvent, and the debt-to-equity ratio as variables to capture the risk of default. The marketability of a firm's bonds is captured by the total market value of all publicly traded bonds. 
Fisher uses multiple regression to test his hypotheses. Cross-sectional regressions were run for five years, 1927, 1932, 1937, 1949, and 1953. His regressions explain about $75 \%$ of the variation in risk premiums with fairly stable coefficients over the test years. Fisher obtains regression coefficients of the expected sign and statistically different from zero in nearly all cases.

Fisher notes a number of methodolical and practical problems with his analysis. Most of $h$ is problems were also experienced in the quantitative analysis for this paper. For example, Fisher notes the difficulties caused by having only bid or asked prices for some bonds and the problems caused by the various terms contained in the bond's indenture. Both of these problems are noted in Section 4 .

\subsubsection{R.A. Haugen, A.L. Stroyny and D.W. Wichern, Rate Regulation, Capital Structure, and the Sharing of Interest Rate Risk in the Electric Utility Industry}

The purpose of the paper by Haugen et al. was to assess the risk associated with public utilities and the extent to which any risk is shared among the shareholders, the bondholders and the consumers. The study contends that the regulated monopoly aspect of the electric utility industry causes it to have some unique risk characteristics, especially in regard to risks associated with changing interest rates. Haugen et al.'s study differs from ours in that it looks at the impact of interest rate changes on the price of the stock. However, at one point the authors do analyze need interest rates for utility bonds. Since they had no yield-to-maturity data for some of their utilities, they used a regression equation of yields-to-maturity to estimate the missing data. The regression equation for yields is quite simple, with only three variables (bond ratings, coupon rates, and term to maturity) along with some nonlinear terms. The results are similar to the ones shown in Section 4 .

The authors conclude that most of the interest rate risk (the sensitivity of asset values to changes in the interest rate) are borne by the shareholders and the bondholders rather than passed on to the final customer. They suspect this is due to regulatory $l a g$ or the use of book values in rate setting. They 
further conclude that a larger percentage of the risk is borne by the shareholders because of utility financing, which includes carrying debt with a shorter duration than the duration of the capital investment.

\subsubsection{Jess Yawitz, An Analytical Model of Interest Rate Differentials and Different Default Recoveries}

Yawitz's paper is a demonstration of several propositions about bond risk premiums, including the proposition that $r$ isk premiums are independent of maturity. The author extends previous models to include both the effect of default probability and the effects of the terms of settlement in the event of a default. He also evaluates the implications of his model for usery limits. He concludes that interest rate ceilings have the effect of requiring additional collateral for settlement in case of default.

2.2.4 I.G. Dambolena and S.J. Khoury, Ratio Stability and Corporate Failure

This article is one of many that have used financial ratios and discriminant analysis to predict corporate failure. The authors' analysis purports to demonstrate it is the instability of ratios over time that can be used to predict failures. In particular the authors use the standard deviation of the financial ratios, the standard error of the estimate of the ratio and the coefficient of variation in the financial ratios. As might be expected, the inclusion of such variables improved markedly the ability of the model to predict failure. 



\subsection{THE ELECTRIC UTILITY INDUSTRY}

Until the early seventies, the electric utility industry was healthy and growing. Because of the economies of scale associated with large power plants, the marginal cost of producing electricity was low. As more customers were added, the average cost of producing electricity continued to fall. The additional customers were due to rapidly increasing uses for electricity and the large post-war population boom. In addition, technologic advances in electric production further led to a decline in rates. However, sometime during the past decade, the financial condition of the electic utility industry peaked. Since that time the industry has declined.

One indicator of the declining financial health of the industry is the industry's decline in market-to-book value for its stocks. Table 3.1 shows market-to-book values for the 64 largest electric utilities over the the past 20 years.

TABLE 3.1. Market-to-Book Values for 64 Largest Electric Utilities (Rated by Sales)

\begin{tabular}{lc} 
Year & $\begin{array}{c}\text { Market to } \\
\text { Book Value }\end{array}$ \\
\cline { 3 - 3 } 1961 & 4.31 \\
1970 & 2.35 \\
1979 & 0.81
\end{tabular}

Source: Computed from McCabe and Helens, Table 3, p.19.

The market-to-book value for electric utilities is now under 1.0, indicating that selling new stock will dilute the equity position of present stockholders. This may indicate resistance by present shareholders to the issuance of new stock.

The electric utilities also are having problems raising funds through the bond market. Traditionally, the utilities' position as a regulated monopoly has meant excellent debt ratings. Recently, as shown in Table 3.2, the debt ratings of the electric utility industry have fallen. 
TABLE 3.2. Standard and Poor's Ratings of Utility

Long-Term Debt (44 Utilities)

Standard and Poor

Rating

$\frac{\text { Year }}{1970 \quad \underline{1979}}$

$A A$ or better

A+ or AA-

A- or A

$\mathrm{BBB}+$ or lower

$64 \% \quad 18 \%$

$0 \quad 29 \%$

$32 \% \quad 32 \%$

$5 \% \quad 21 \%$

Source: Platt, Table 5, p. 20.

Table 3.2 indicates the reduction of utility long-term bond ratings. The number of utilities with ratings of BBB+ or lower increased from $5 \%$ to $21 \%$. Only four of the 44 utilities in this survey had improvements in their bond ratings, 26 had their ratings reduced.

Taken together, Tables 1 and 2 show the deteriorating financial health of electric utilities. This deterioration has led to the cancellation of new projects, the delay of additional capacity, and a concern that the industry may soon face financial crisis--a crisis that could include bankruptcy for some utilities.

There are a number of reasons for the decline in financial health. The rapid increase in oil prices, problems with increasing construction costs and schedules, increasing regulation by states and the federal sector and delays in state approval of rate increases. Added to these problems was the accident at Three Mile Island (TMI), which has changed investors' notions about the costs of nuclear power and the possiblity of utility bankruptcy. This section documents and discusses the causes for the overall decline of electric utilities as well as the specific effects of TMI.

\subsection{FUEL COSTS}

Recent increases in fuel prices have contributed substantially to increased utility generation costs. Since the oil embargo and the attendent increase in the price of oil, utilities have reduced the share of oil in the generation mix. Table 3.3 shows how fuel prices have changed over the last 20 years. 
TABLE 3.3. Annual Percentage Change in Fue 1 Costs (\$/MBtu)

\begin{tabular}{|c|c|c|c|c|c|c|}
\hline \multirow[t]{2}{*}{ Year } & \multicolumn{3}{|c|}{ Nominal Change } & \multicolumn{3}{|c|}{$\frac{\text { Nominal Change Deflated by }}{\text { Producer Price Index }}$} \\
\hline & Coal & $\underline{0 i 1}$ & Gas & $\begin{array}{l}\text { Produc } \\
\text { Coal }\end{array}$ & Price & $\underline{\underline{x}} \underline{\underline{G a s}}$ \\
\hline $1962-1965$ & $-1.3 \%$ & $-1.8 \%$ & $0 \%$ & $-1.8 \%$ & $-2.3 \%$ & $-0.5 \%$ \\
\hline $1965-1970$ & 5.0 & 12.0 & 0.6 & 2.2 & 9.2 & -2.2 \\
\hline $1970-1975$ & 23.6 & 47.4 & 29.2 & 15.3 & 39.1 & 20.9 \\
\hline $1975-1980$ & 10.5 & 15.3 & 25.8 & 2.1 & 6.9 & 17.4 \\
\hline
\end{tabular}

Source: Reported in Fang and Harrer, Factors Influencing Electric Utility Energy Conservation Programs. PNL-3854, Pacific Northwest Laboratory, April 1981.

The real increase in the price of inputs to the generation of electricity is an important contributor to the increase in the cost of producing electricity. Since 1970, fuel prices have increased over 500\% (Edison Electric Institute $1979, p .46)$. In an attempt to mitigate the effect of the cost increases, electric utilities increased construction of nuclear generating facilities and began revolving-door attempts to pass the cost increases through to utility customers. As described in the following subsections, neither of these reactions were successful in avoiding financial problems.

\subsection{CONSTRUCTION COSTS AND SCHEDULES}

The response of utilities in the late sixties and early seventies to the growing demand for electricity was to accelerate the building of large generating facilities. For reasons relating to the oil embargo and a variety of federal subsidies of nuclear production (for example, the Price-Anderson Act, which is the federal insurance scheme for limited utility liability), most planned new generating facilities were nuclear. At the time many of the decisions were being made to build nuclear facilities, nuclear plants were coming on line on schedule in about 6-8 years. As larger plants were built and the architect-engineers were gaining experience, costs per KWe were falling (Nesse et al. 1979). As discussed below, these early expectations did not materialize. 
The total construction time and capital cost of a nuclear power plant are measures of a complicated production process. The final costs and construction times depend on such relatively predictable variables as the price of labor to such unpredictable variables as the weather. Since these costs must be estimated years before they are incurred, some variance from expected costs must be assumed. However, putting the pieces together in actually designing and constructing a nuclear facility has become more difficult than anticipated. Up to four million manhours may be required to complete just the total design process (Nesse et al. 1979).

With long gestation periods in a period of rather high and unstable inflation, it is not surprising capital costs have increased. It is surprising, however, how much faster nuclear and coal fired power plant capital costs have increased beyond the rate of inflation. One study (Nesse et al. 1979) found that the nominal increase in the cost of constructing a steam electric generating plant was $120 \%$ compared to a $55 \%$ increase in the general price level. Another study (Nieves et al. 1980) found that from 1968 to 1977 the capital costs for nuclear plants rose at a real annual rate of $11 \%$ and the capital costs for coal plants rose at a real annual rate of $5 \%$.

There are a number of interrelated causes for the real increase in the capital costs of steam electric generating facilities. Since 1973 power plant construction cost increases have outstripped overall construction cost increases (Nesse et a1. 1979), thus indicating the set of factors causing power plant cost increases to be different than the set of factors affecting other types of heavy construction costs. Added to the construction cost increases are management's inability to deal with marmoth construction schedules, and federal and state regulations which often require retrofitting and expensive construction delays.

It is not just increasing and uncertain construction costs which are causing the financial problems of utilities. The length of time required to bring a nuclear plant on line has experienced similar increases. Utilities are usually unable to include construction work in progress into the rate base. These delays create additional uncertainty about when the utility may begin to receive a return on its investment. Using the elapsed time from application of the plant's construction permit to the issuance of the operating license as the 
length of the construction period, multiple regression was used to estimate the temporal increase in construction times. The results of the regression are shown in Table 3.4. The sample consisted of plants that had come on line as of 1978.

TABLE 3.4. Results of Econometric Modelling of Construction Length ( $T$-Values in Parenthes is)

\begin{tabular}{|c|c|}
\hline Variable & Coeffi \\
\hline Constant(1971) & $\begin{array}{l}56.6 \mathrm{~m} \\
(13.1)\end{array}$ \\
\hline NEPA & $\begin{array}{c}6.2 \\
(2.2)\end{array}$ \\
\hline D-1972 & $\begin{array}{l}10.4 \\
(1.8)\end{array}$ \\
\hline D-1973 & $\begin{array}{l}19.6 \\
(4.2)\end{array}$ \\
\hline D-1974 & $\begin{array}{l}18.3 \\
(3.9)\end{array}$ \\
\hline D-1975 & $\begin{array}{l}28.0 \\
(5.3)\end{array}$ \\
\hline D-1976 & $\begin{array}{l}41.8 \\
(7.4)\end{array}$ \\
\hline D-1977 & $\begin{array}{l}59.8 \\
(9.5)\end{array}$ \\
\hline D-1978 & $\begin{array}{l}31.6 \\
(5.7)\end{array}$ \\
\hline
\end{tabular}

R-Squared - 85\%

The regression coefficients for the dummy variables for each year show the additional construction time above 1971 's (56 months) required to bring the nuclear plant on line. For example, the total licensing and construction time for a plant that came into comercial operation in 1971 is 56.6 months (the constant term), whereas one in 1977 took on average 59.8 months longer (the coefficient on D-1977). In other words, the mean time for a plant to come on line in 1977 was $56.6+59.8$, or about 116 months.

The regression results displayed in Table 3.4 indicate the increases in time required to bring a nuclear plant on line. The average time in 1977 was about 10 years. Indications are that the $t$ ime required may be presently around 12 years or more. This length would appear to be approaching the utilities' ability to forecast electricity demand. 
A similar analysis of coal plants revealed little temporal increase in the time required to bring a coal plant on line. Thus, utilities that are heavily into the construction of nuclear plants may be damaged greater than the overall industry.

\subsection{REGULATIONS}

The electric utility industry is one of the most regulated industries in the economy. The state public utility commission sets the allowed rates of return and the rates paid by the utility's customers. The energy field has been heavily subsidized, researched, developed, and regulated by the federal government. Construction and operation of power generating facilities are regulated by both the state and federal governments.

The NRC is responsible for ensuring the safety of nuclear power plants. The industry has maintained that the NRC has regulated the industry to the point where the costs of the regulations far exceed their benefits. Many NRC regulations occur through the issuance of "Regulatory Guides." The Guides are taken by the industry as requirements that must be complied with before permits will be issued. Figure 3.1 shows the growth in NRC Regulatory Guides during the 1970 's.

There is little doubt that regulations have increased the costs of constructing steam electric power plants. (Nesse et al. 1979). It is difficult to assess either the relative impacts of regulations on nuclear versus coal fired power plants or the impacts of regulation isolated from construction problems and mismanagement. Public concern over the possible impacts of excess regulation on electric utilities was quieted by the impacts of the largest U.S. nuclear accident to date at the Three Mile Island Nuclear Power Plant.

\subsection{THREE MILE ISLAND}

By early 1979, the nuclear industry's financial situation was depressed. Inflation, regulation, construction problems, and mismanagement were creating public concern over the cost of nuclear power. Additional concerns were voiced over the safety of nuclear power. During this period of concern over the cost and safety of nuclear power, remaining public and investor faith was jarred by the accident at TMI. 


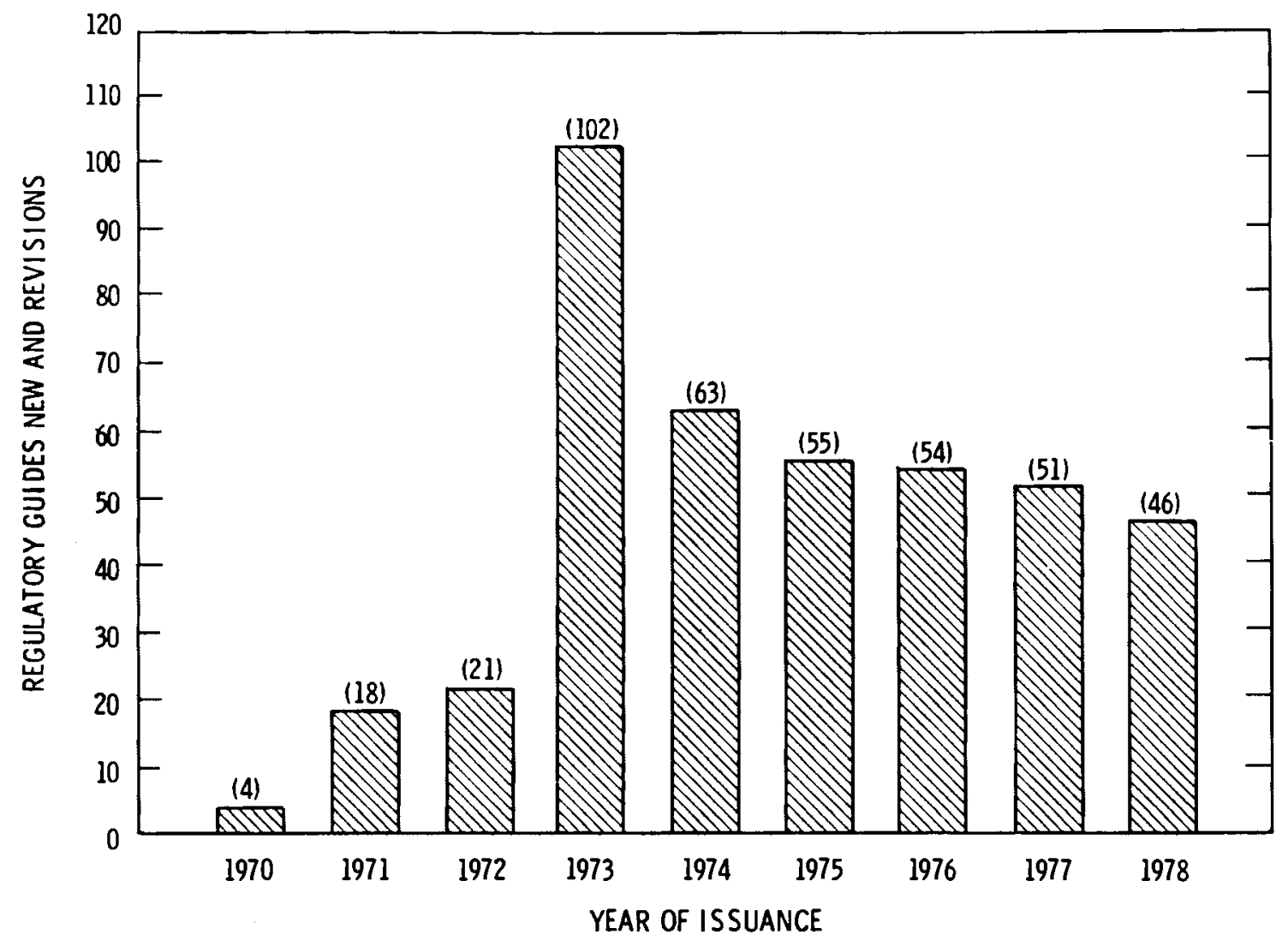

FIGURE 3.1. Yearly Growth in NRC Regulatory Guides

The accident could not have been more ill-timed for those utilites with large investments in nuclear power. It created three types of concern for investors: 1) whether nuclear accidents were more common and more expensive than previously believed, 2) whether the utilities would be liable for damages exceeding the limits of their insurances, and 3 ) whether and to what extent the costs of the accident would be borne by the utility, the utility's customers, or the federal government.

This section briefly describes the TMI accident and how it might affect shareholders of the utilities involved. This will provide information on how investors may respond to utilities with heavy nuclear involvement.

On March 28, 1979, a nuclear plant, Three Mile Island 2, suffered an accident with a resulting release of low-level radiation. TMI-2 is jointly owned by three utilities, Jersey Central Power and Light (25\% ownership), Metropolitan Edison Company (50\%), and Pennsylvania Electric Company (25\%). The parent 
company for all three of these utilities is General Public Utilities (GPU). As a result of the damage at TMI-2, GPU was forced to shut down a companion nuclear plant, TMI-1, until TMI-2's damage could be surveyed. TMI-1 would be down for at least two years.

Estimates of the costs for cleaning up TMI are staggering. The first estimates were prepared by the Bechtel Power Corp. Their estimates--little more than educated guesses--were that the cleanup costs would be $\$ 400$ million and take four years. This was before the extent of the damages could be accurately estimated. Subsequent estimates were higher. A revised estimate placed the cost of decontaminating the unit at almost $\$ 600$ million. Other restoration of the unit would require $\$ 260$ million, with an additional $\$ 90-100$ million for compliance with NRC regulations promulgated as a result of TMI. At the peak of the cleanup effort, as many as 900 workers will be required. The total cost is expected to be somewhere around $\$ 950$ million (Moody's 1980).

Since the accident at TMI is a unique event, it is unclear who will pay the cleanup costs. Private insurance is expected to cover $\$ 117.1$ million. Another layer of coverage is provided by a risk-pooling arrangement among utilities with nuclear plants. GPU expects about $\$ 300 \mathrm{million}$ to be covered by assessments on existing nuclear reactors. In addition, GPU hopes that the federal government will cover some of the costs of removing, handling, and storing the nuclear waste as a type of research grant in order to learn more about these tasks.

The effect of TMI on GPU could be disastrous. GPU has already reduced its dividend in half, cut its workforce by 600 people, and stopped work on two large plants. (Business Week 1979). Meanwhile, it must continue to meet its debt obligations on TMI-1 and -2 and continue to purchase higher cost replacement power. A more serious problem is that the Public Utility Commissioners of both states (Pennsylvania and New Jersey) have stated that the costs of TMI will not be recoverable from ratepayers. Both states have taken TMI-1 and -2 out of the utilities' rate bases. This forces GPU to reduce its revenues and moves the utility closer to bankruptcy. While fines by the NRC have to date been relatively small $(\$ 155,000)$, The NRC has threatened to revoke TMI's operating license unless GPU is able to obtain adequate insurance. The Pennsylvania Public Utility Commission has considered withdrawing G.P.U.'s right to operate a public utility. 
The effect of TMI on the electric power industry has been substantial. No new nuclear plants were given operating permits for two years following the accident. Utilities were unable to collect a return on nuclear power plant investments of 100's of million dollars. The accident raised the spectre that nuclear accidents might be much more common and much more expensive than previously estimated. Liability and total costs are still unclear. However, two effects are clear. At a minimum, the perceived risk of building a nuclear power plant has increased. Accompanied with that increased $r$ isk is the real possibility that a utility could be forced into bankruptcy.

A cursory quantitative examination of the magnitude of the impact of TMI on the electric utility industry is examined in the next section. While the extent of the analys is is somewhat limited, evidence is found supporting the hypothesis that investors require risk premiums for bonds of electric utilities owning nuclear power plants. 



\subsection{QUANTITATIVE RESULTS}

This section describes the statistical procedures and tools used to test the hypotheses and the results of the empirical analysis. The models and major statistical tool, multiple regression, recognize utility interest rates and bond ratings differ for a variety of reasons. Multiple regression is capable of dealing with interest rate or bond rating differences and still evaluating the impact of Three Mile Island and utilities' use of nuclear power. This section also sumarizes the results of the statistical analys is using multiple regression.

\subsection{MULTIPLE REGRESS ION}

Empirical research in the social and physical sciences often involves attempts to measure the effect on one variable of changing another variable. Since such research demands that other conditions remain constant, the physical sciences usually attempt experiments under controlled, laboratory conditions. Because social scientists rarely have the opportunity to conduct such experimental research, they have developed statistical means of controlling for the effects of numerous variables. Multiple regression is a statistical tool which has been widely used for such purposes in empirical research in the social sciences. For example, utility bond ratings likely depend on the ability of the utility to cover interest and other fixed charges. In addition, the ratings may depend on the strictness of the state's public utility committee or board. For this research, we have hypothesized that bond ratings also depend on size of the utility's participation in nuclear power.

Regression analysis postulates a relationship between a variable referred to as the dependent variable and one or more independent variables. The value for the dependent variable is considered to depend on the values of the independent variables. The relationship is usually written:

$$
y=B_{0}+B_{1} X_{1}+B_{2} X_{2}+\ldots B_{n} X_{n}+e
$$

with $Y$ as the dependent variable, the $X$ 's the independent variables, and $e$ representing an "error" term. The error term is designed to capture such 
effects as variables omitted because of data limitations, errors in measuring the variables and random fluctuations or chance occurrences. One objective of regression analysis is to obtain estimates of the coefficients of the independent variables, the $\mathrm{Bi}^{\prime} \mathrm{s}$. These coefficients represent the impact on the dependent variable of a one-unit change in the independent variable. For example, holding all other independent variables constant, increasing $X_{1}$ by one unit causes a change in $Y$ of $B_{1}$.

Multiple regression was used to evaluate the differences among utility bond interest rates and the Moody's bond rating for each utility in the sample. The discussion below describes the data and variables used in the regression equations.

\subsection{VARIABLE DESCRIPTION}

The multiple regression analysis was based on a sample of data from 63 private utilities. The following subsections define the variables used in the statistical analysis.

\subsubsection{Utilities}

The utilities used in the regression analysis were all private utilities with a total capitalization of at least 1 billion dollars. In addition, utilities were included only if data on all variables used in the regression were available. The final analysis was based on the 63 utilities that met these criteria.

\subsubsection{Interest Rates}

Interest rates were used as the dependent variables for several of the regression equations. The interest rates used were yield to maturity on December 31, 1980, for bonds maturing in 25 years. When a 25-year bond could not be identified for a particular utility, the issue maturing as close as possible to a 25-year bond was used. Since most of the utilities issue bonds yearly, there was little problem obtaining bonds with comparable maturity dates.

\subsubsection{Bond Ratings}

While the primary evidence is that investors have reacted negatively to Three Mile Island and to the rash of other problems affecting utilities 
involved in nuclear power, differences among the utility bonds might swamp any statistical evidence of the impact from nuclear participation. Other evidence of uneasiness about nuclear power could be differences in ratings of the quality of the utilities' bonds. The Moody's bond rating for each of the bonds in the sample was collected. The ratings were transformed to a quantitative variable based on the following:

\begin{tabular}{lc} 
Bond Rating & Value of Variable \\
\cline { 2 - 2 } Aaa & 1 \\
Aa & 2 \\
A & 3 \\
Baa & 4 \\
Ba & 5 \\
B & 6
\end{tabular}

The bond ratings were obtained from Moody's Bond Record, January 1980.

\subsubsection{Percent Nuclear Participation (\% Nuclear)}

The variable used to capture the expected level of nuclear participation by the utility was the expected fuel mixture for generation in 1982 . The figure for 1982 was used to incorporate those plants which are presently being built. The source for this variable was Merri11, Lynch, Pierce, Fenner and Smith's Electric Utility Industry, Financial Summary - 1979.

\subsubsection{Times Charges Earned}

Times Charges Earned (TCE) is an important determinant of both the utility's bond ratings and the yield to maturity on its debt. The ratio provides information on the ability of the utility to repay its debt obligations from current operating cash. Data on TCE were collected for both 1979 (reflecting the present status of the utility) and 1978 (representing the figure reported for the preceding year). The 1978 TCE was collected for two reasons. First, the previous year's figure may show the effect of a recent trend which might be reflected in interest rates or bond ratings. Second, the TCE for 1979 would not have been reported by the end of 1979. Although quarterly figures may be available to investors, bond ratings and interest rates may be influenced by the utility's TCE for the last full year. 


\subsubsection{State Regulatory Quality}

An important determinant of bond quality and possibly interest rates is the quality of the state commission which regulates the utility operation. The state regulatory commission can shorten or lengthen the time from rate filing to final decision and increase or decrease allowed rates of return or the rate base. In addition, state commissions vary in the consistency of applying the principles and handling issues. Differences in how the state regulatory commission applies the regulatory process are important to investors.

The ratings of state regulatory quality are from Merrill Lynch's Electric Utility Industry. The utilities, based on the above criteria, are rated from 1 (lowest quality) to 5 (highest quality). The higher quality is an indication the state commission tends to act favorably and rapidly for investors.

\subsubsection{Three Mile Is land (TMI)}

Three of the utilities in the sample were subsidiaries of General Public Utilities, the owner of Three Mile Island. These three, Jersey Central Power and Light, Pennsylvania Electric, and Metropolitan Edison, were assigned dummy variables to measure the reaction to the accident on their bond yields and ratings.

\subsubsection{Size}

Size of the utility was measured by generating capacity (in megawatts) of the utility in 1979.

\subsubsection{Sinking Fund}

A dummy variable was used to indicate the presence of a sinking fund for the utility's bond. A sinking fund should reduce the risk of nonpayment of the bond's principal.

\subsection{RESULTS}

This subsection reports the most significant results of the regression analys is for bond ratings and yields to maturity. These results must be viewed as preliminary, since the scope of this study precluded an extensive analysis. 


\subsubsection{Bond Ratings}

In most cases, regression equations relating bond ratings to a number of independent equations performed reasonably we11. Variables were entered with significant $t$-values (a measure of whether or not the regression coefficient can be said to be different from zero) and most of the variations were explained. Table 4.1 displays the results for one of the regressions.

TABLE 4.1. Regression Results for Bond Ratings

\begin{tabular}{|c|c|c|}
\hline Independent Variable & Coefficient & T-Value \\
\hline Constant & 5.50 & 15.58 \\
\hline \% Nuc lear & .01 & 3.03 \\
\hline State Regulatory Qual. & -.02 & -.22 \\
\hline TCE-1979 & -.50 & -3.84 \\
\hline TMI & 1.90 & 5.69 \\
\hline TCE-1978 & -.47 & -3.34 \\
\hline R- Squared & $70.6 \%$ & \\
\hline Adjusted R-Squ & red $68.5 \%$ & \\
\hline
\end{tabular}

The interpretation of the results are straightforward. The dependent variable, bond ratings, is coded such that a lower value means a higher-quality bond. For example, the regression equation shows that that an increase of 1 in the times-charges-earned ratio decreases the score for bond ratings by .50 . The decrease in the score translates to an increase in the quality of the bond. Thus, as expected, an increase in times-charges-earned increases the quality of the bond rating. Similarly, an increase in nuclear participation causes a decrease in bond ratings. An increase by $20 \%$ of the electricity generated by nuclear causes a small but statistically significant decline in bond ratings.

The largest coefficient is the impact of Three Mile Island on bond ratings. After adjusting for different coverage ratios and nuclear participation ratios, the impact of TMI was large. The bond rating of the utilities owning TMI fell by almost 2 ratings. For example, a utility with the same values as a TMI utility for the other independent variables might have a bond rating Aa. The TMI utility rating would be about Baa. 
Unexpectedly, the regression coefficient for the quality of the state regulatory commission had no effect on bond ratings once the other variables were included in the equation. Apparently, the results of a better state regulatory commission are manifest in higher times charges earned or other variables already in the equation.

A number of other forms of the equation were tried. It seemed to make little difference whether the variables were in logs or not. The inclusion of interaction terms and several other variables contributed little to the equation's explanatory power.

A simpler analysis was performed to test the differences in bond ratings between utilities with large and small percentages of their electricity generated by nuclear facilities. The sample of utilities was divided into three groups: those which expect less than $25 \%$ of their electricity to be generated from nuclear plants, those which expect 25-50\%, and those which expect over $50 \%$. The bond ratings for the three groups were compared. The differences in bond ratings were statistically significant, with the best ratings to those utilities with few nuclear plants and the lowest ratings to those with over 50\% of the ir electricity generated from nuclear plants.

\subsubsection{Bond Interest Rates}

The regression equations for bond interest rates did not perform as we 11 as those for bond ratings. In general, the R-squares were lower, fewer variables were statistically significant, and there were several cases of variables with unexpected signs. There are several possible reasons for this. Bond yields differ because of differences in bond provisions as well as because of differences in the risk or quality of the utility. Different bonds may have different call provisions, sinking fund provisions, tax status, or default provisions. In addition, some yields are based on sales prices, others on bid prices. Adjustments were made for many of these provisions, and attempts were made to correct for differences in sinking fund provisions and whether the yield was based on a bid or sales price. All bonds were approximately the same length to maturity. However, these corrections may not have been enough to capture the effects of nuclear participation on bond yields. 
An alternative explanation is that the effect of many of the variables on bond yields may have entered through the bond rating. Inclusion and exclusion of bond ratings as an independent variable had a large effect on coefficients and $t$-values. Table 4.2 shows the results of a regression equation that explains the variation in bond yields using bond ratings as an independent variable.

\section{TABLE 4.2. Regression Results for Bond Yields}

\begin{tabular}{|c|c|c|}
\hline Independent Variable & Coefficient & T-Value \\
\hline Constant & 11.99 & 27.36 \\
\hline Bond Rating & .35 & 4.50 \\
\hline Nuclear Participation & -.01 & -.44 \\
\hline TMI & 1.12 & 3.36 \\
\hline TCE-1978 & -.18 & -1.87 \\
\hline Utility Growth & -.01 & -2.81 \\
\hline R-Squared & $74.6 \%$ & \\
\hline Adjusted R-S & $72.4 \%$ & \\
\hline
\end{tabular}

Excluding the nuclear participation variable had only a small impact on the coefficients and t-values of the other variables. Again, the impact of TMI on the three utilities that were directly affected is large. The interest rates for those utilities rose, on average, $1.12 \%$. This reflects investor concern about the huge cleanup costs and possible bankruptcy. Bond ratings appear to play a large role in explaining interest rates. It is impossible to determine from the regression analys is whether investors base judgments on the basis of the ratings or whether both ratings and investor decisions are based on the same underlying characteristics of the utility. The expected percent growth of the utility was added to capture expectations about future earnings on the utility. A utility in a high-growth area (for example, the southwest) would be expected to have growing earnings. This would mean investors would be willing to pay a premium for their bonds. This was confirmed by the regression equation. The variable was significant and of the expected sign. 


\subsection{CONCLUSIONS}

The last 10 years have been extraordinary for the electric utility industry. The industry has experienced a number of problems: 1) utilities are no longer a decreasing-cost industry and must adjust to one of rapidly increasing costs, 2) construction problems were experienced for all types of power plants but especially for nuclear, 3) inflation has ravaged utilities' earnings, and 4) regulatory lags have prevented utilities from passing their problems onto their customers. Added to these problems was the accident at Three Mile Island Nuclear Power Plant. The magnitude of the accident left the electric industry, investors, and the general public stunned and concerned about the safety of nuc lear power.

The above problems have not gone unnoticed by investors or bond raters. The regression analys is in Section 4 showed that the impact of Three Mile Island has been significant on the participating utilities. In addition, utilities with a high percentage of their electricity generated by nuclear power plants were found to have lower bond ratings. The results were less clear, however, for bond interest rates. For these, either one of three possibilities remain. The first possibility is that the effects of increased nuclear participation are manifest through utility bond ratings to higher interest rates; that is, there is no additional risk premium for nuclear participation above that captured by the reduced bond ratings. A second possibility is that the impact of nuclear participation is obscured by the inability to quantitatively hold constant a 11 of the bonds' terms; that is, the provisions of sinking fund requirements, call provisions, and default provisions require a more careful analysis of bond interest rates. A third possibility is that nuclear participation does not matter to investors; that is, while Three Mile Island may have been disastrous to the affected utility, investors do not believe the incident provided any new information on the risks associated with nuclear power.

This study has barely scratched the surface of either the general issue of firm bankruptcy or the estimation of risk premiums in the electric utility 
industry. A much more careful review of the literature is necessary as is a more careful quantitative analys is of bond interest ratings. However, this study has revealed a great deal about the impacts of the risk of nuclear power on utility financing and the implications for debt risk premiums. 


\section{REFERENCES}

Dambolena, I.G., and S.J. Khoury. 1980. "Ratio Stability and Corporate Fai1ure." J. of Fin. 35(4):1017-1026.

Edison Electric Institute. 1980. Statistical Year Book of the Electric Utility Industry/1979. Edison Electric Institute, Washington, D.C.

Fang, J.M., and B.J. Harrer. 1981. Factors Influencing Electric Utility

Energy Conservation Programs. PNL-3854, Pacific Northwest Laboratory,

Richland, Washington.

"Financial Fallout at GPU." Business Week, July 30, 1979.

Fisher, L. 1959. "Determinants of Risk Premiums on Corporate Bonds." J. of Pol. Econ. 67(3):217-237

Higgins, R.H. 1977. Financial Management: Theory and Applications. Science Research Associates, Chicago, I11inois.

Haugen, R.A., A.L. Stroyny, and D.W. Wichern. 1978. "Rate Regulation, Capital Structure, and the Sharing of Interest Rate Risk in the Electric Utility Industry." J. of Fin. 23(3):707-721.

McCabe, G.B., and B.P. Helms. 1981. "Are Tender Offers Viable Options for Debt Management." Public Utilities Fortnightly. $107(2): 28-34$.

Merri11, Lynch, Pierce, Fenner, and Smith. 1980. Electric Utility Industry, Financial Summary - 1979. Merri11, Lynch, Pierce, Fenner and Smith, New York, New York.

Moody's Investor Services. 1980. Moody's Bond Record, January 1980. Moody's Investory Services, Inc., New York, New York.

Nieves, L.A., et a1. 1980. The Marginal Cost of Electricity 1980-1995: An Approximation Based on the Cost of New Coal and Nuclear Generating Plants. PNL-3458, Pacific Northwest Laboratory, Richland, Washington.

Nesse, R.J., et a1. 1979. The Impact of Regulatory Requirements on SteamElectric Power Plants. PNL-3339, Pacific Northwest Laboratory, Richland, Washington.

Platt, H.D. 1981. "The Electric Utility Outlook to the Year 2000." Public Utilities Fortnightly. $107(2): 17-23$.

Yawitz, J.B. 1977. "An Analytical Model of Interest Rate Differentials and Different Default Recoveries." J. of Fin. and Quan. Analysis. 12(3):481490. 


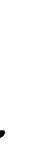




\section{DISTRIBUTION}

No. of

Copies

\section{OFFSITE}

\section{A. A. Churm}

DOE Patent Division

9800 S. Cass Avenue

Argonne, IL 60439

\section{A. Meltz}

Office of Regulatory Analysis

FERC

825 North Capitol St. N.W.

Washington, D.C. 20426

J. Thereault

Office of Plans and Evaluations

Assistant Secretary for

Nuc lear Energy

Department of Energy

1000 Independence Ave. S.W.

Washington, D.C. 20585

K. Trickett

Office of Nuc lear Energy

Department of Energy

Germantown, MD 20874
27 DOE Technical Information

Center

ONSITE

DOE Richland Operations Office

H. E. Ransom

33 Pacific Northwest Laboratory

J. B. Burnham

J. W. Currie

D. E. Deonigi

R. M. Fleischman

R. J. Nesse (15)

D. R. Payson

L. D. Schmid

L. D. Williams

T. L. Willke

Economics Library (3)

Publishing Coordination (2)

Technical Information (5) 
